\title{
Rozwój technologii informacyjnych szansą czy zagrożeniem dla społeczeństwa obywatelskiego?
}

Informacja stanowiła od zawsze ważny element funkcjonowania ludzkości ${ }^{1}$. Poczynając od starożytności, wiedza o tym, gdzie znaleźć pożywienie lub źródło pitnej wody, miała niebagatelne znaczenie dla założycieli greckich polis. Była ona również ważna dla pierwszych osadników w Ameryce Północnej, traperów odkrywających nowy nieznany kontynent. Informacja o szlakach handlowych do Indii czy w głąb Afryki, dzięki którym do Europy kupcy sprowadzali nie tylko oryginalne i wcześniej niespotykane towary, ale również wiedzę o ekosystemie i strukturze społecznej ludności tubylczej, kształtowała świadomość ówczesnych Europejczyków. Informacja odegrała również ważną rolę na przełomie XVIII i XIX w., kiedy to rozpowszechniające się idee Wielkiej Rewolucji Francuskiej dały początek wielkiej fali przemian ustrojowych na ówczesnej mapie świata. Niebagatelną rolę odegrała także w historii Polski zarówno procesie uchwalania Konstytucji 3 maja w 1791 r., jak również w trakcie działalności konspiracyjnej przygotowującej kolejne niepodległościowe powstania. Równie istotne znaczenie należy jej przypisywać podczas XIX-wiecznej rewolucji przemysłowej. Rozpowszechnienie wiedzy, innowacyjnych rozwiązań technologicznych oraz nowych schematów produkcji stało się kołem zamachowym nowoczesnego świata. Wtedy jednak, w trakcie dynamicznego procesu industrializacji, większą uwagę przywiązywano do kapitału oraz sił wytwórczych, czego dobitny przykład dał Karol Marks i jego Kapitał. Współcześnie jednak politycy i specjaliści z zakresu polityki, socjologii i ekonomii podkreślają znaczenie posiadania informacji jako: wiedzy na temat bieżących wydarzeń w szeroko rozumianej sferze społecznej, wiedzy o tym, jak pozyskać niezbędne informacje tzn. know-how, oraz wiedzy w zakresie znajomości środowiska społecznego, ekonomicznego i politycznego ${ }^{2}$.

1 Zdaniem niektórych badaczy paradygmat cywilizacyjny określają trzy żywioły: materia, energia i informacja. Zob. K. Krzysztofek, M.S. Szczepański, Zrozumieć rozwój-od społeczeństw tradycyjnych do informacyjnych, Katowice 2002, s. 176.

2 P.F. Drucker, The Knowledge Economy, Boston 1998, s. 15-33. 
O znaczeniu informacji, szczególnie w wymiarze politycznym, świadczą wydarzenia początku XX w., naznaczone jarzmem dwóch wielkich totalitaryzmów: komunizmu oraz nazizmu. Powszechnie wiadomo, jak ważną rolę stanowiła ona $\mathrm{w}$ aparacie represji władzy oraz w sferze prowadzenia polityki wewnętrznej i zagranicznej. Informacja, a niekiedy dezinformacja, zaczęła stanowić atrybut propagandy. Współcześnie pełni ona inną rolę, równie istotną w wymiarze społecznym oraz politycznym, stanowiąc element stymulujący zaangażowanie ludzi w proces zarządzania państwem. Szczególną rolę pełni ona w państwach liberalnej demokracji, gdzie podmiotowość społeczna stanowi niebagatelne znaczenie zarówno dla elit politycznych, które muszą zdobyć przychylność wyborców w cyklicznych wyborach, jak i dla samych obywateli, którzy mają prawo i instrumenty do tego, aby wyrażać swoją wolę, realizować interesy, wygłaszać poglądy o rządzących. Informacja dla współczesnych społeczeństw obywatelskich stanowi kluczowy element ich funkcjonowania ${ }^{3}$. To swoiste zaangażowanie jednostki w państwo i społeczeństwo rozumiane jako samorządność w wymiarze lokalnym, aktywność w sferze publicznej czy wreszcie działalność w organizacjach pozarządowych stanowi ważny budulec kultury politycznej oraz tworzy ramy prawne i moralnie akceptowalne zasady postępowania ${ }^{4}$. Należy stwierdzić, że nie miałyby one możliwości istnienia, gdyby nie dostęp do informacji oraz możliwość reagowania na nią, co doskonale zostało zilustrowane w modelu komunikacji politycznej stworzonym przez C. Shannona i W. Weavera ${ }^{5}$.

Rozważania nad dystrybucją informacji prowadzą do refleksji nad funkcjonowaniem współczesnego świata oraz społeczeństwa informacyjnego, czyli takiego, w którym informacja wykorzystywana jest we wszystkich aspektach życia, a zatem jej przetwarzanie wpływa na kształtowanie dochodu narodowego, stabilność państwa oraz bezpieczeństwo ludności cywilnej ${ }^{6}$. Według amerykańskiego ekonomisty Fritza Machlupa, aż 29\% produktu krajowego brutto w USA w latach 50. stanowiła tzw. produkcja dystrybucji wiedzy, czyli informacja. Stwierdził on także, że blisko $31 \%$ osób aktywnych zawodowo było zatrudnionych w gałęzi gospodarki zajmującej się ,produkcją i przetwarzaniem informacji”" Należy przypuszczać, że obecnie wynik ten jest znacznie większy. Informacja staje się więc dobrem nieuchwytnym, jednocześnie powszechnie pożądanym, a zatem każdy chce mieć dostęp do niej i instrumenty umożliwiające jej redystrybucję.

3 Społeczeństwo obywatelskie zdaniem R. Putnama to przede wszystkim „wzory zaangażowania obywatelskiego i solidarności społecznej”. R. Putnam, Demokracja w działaniu. Tradycje obywatelskie we współczesnych Włoszech, Warszawa 1993, s. 126.

${ }^{4}$ D. Pietrzyk-Reeves, Idea społeczeństwa obywatelskiego, wspótczesna debata i jej źródła, Wrocław 2004, s. 17.

${ }_{5}^{5}$ M. Kolczyński, Strategie komunikowania politycznego, Katowice 2008, s. 18.

${ }^{6}$ A. Szewczyk, Spoleczeństwo informacyjne - problemy rozwoju, Warszawa 2007, s. 19.

${ }^{7}$ Ibidem, s. 11. 
Warto zatem podjąć rozważania na temat miejsca społeczeństwa obywatelskiego w świecie nieustającego rozwoju technologii informacyjnych oraz w perspektywie przenoszenia się kolejnych sfer życia publicznego w przestrzeń wirtualną. W tym wymiarze partycypacja społeczna, rozumiana w klasycznym ujęciu jako udział w wyborach, zabieranie głosu na wiecach czy spotkania lokalnej społeczności nabiera nowego znaczenia. Orędownicy postępu multimedialnego kładą nacisk na zalety, jakie posiada powszechny dostęp do Internetu w sferze aktywności obywatelskiej. Z drugiej strony, zauważalna jest w ostatnich latach tendencja do degeneracji dyskursu publicznego toczonego w sieci, a panujący w niej chaos komunikacyjny zniechęca wiele osób do traktowania jej jako rzetelne źródło informacji. $Z$ tego powodu rodzi się wątpliwość, czy rozwój technologii informacyjnej jest szansą, czy zagrożeniem dla społeczeństwa obywatelskiego.

\section{Przegląd literatury}

Wpływ rozwoju technologii informacyjnej na funkcjonowanie społeczeństwa interesuje naukowców na całym świecie. Z badań wynika, że nowoczesne rozwiązania technologiczne stają się istotnym narzędziem komunikacji politycznej, wykorzystywanym przez polityków na poziomie lokalnym, krajowym oraz międzynarodowym. Równie chętnie korzystają z niego obywatele w sferze prywatnej również po to, aby śledzić poczynania rządzących, komentować lub wyrażać sprzeciw wobec bieżących działań władz. Efektem tego jest powstanie społeczności, której miejscem spotkań jest Internet kumulujący informacje, zbierający opinie, a zatem wpływający na bieżącą politykę i nastroje społeczne.

Zespół badaczy z Włoch, Hiszpanii i Szwajcarii podjął się zadania zebrania informacji na temat procesu wdrażania technologii informacyjnej i komunikacyjnej oraz jej wpływu na społeczeństwo, zgodnie z paradygmatem społeczeństwa informacyjnego ${ }^{8}$. Ich praca prezentuje to zjawisko w trzech wymiarach. W pierwszej kolejności jest nim oddziaływanie na sferę ekonomii, w drugiej na sferę usług publicznych, a w kolejnej na tzw. eGovernment, czyli usługi publiczne świadczone przez Internet ${ }^{9}$. G. Misuraca, C. Codagnone i P. Rossel doszli do wniosku, że nie sposób na obecnym etapie badań wykazać, że rozwój technologii informacyjnej ma znaczący wpływ na procesy zachodzące w gospodarce, polityce i społeczeństwie ${ }^{10}$. Nie oznacza to jednak, że nie ma go wcale, ponieważ w procesie

${ }^{8}$ G. Misuraca, C. Codagnone, P. Rossel, From practice to theory and back to practice: Reflexivity in Measurement and evaluation for evidence-based policy making in the information society, „Government Information Quarterly” 2013, vol. 30, s. 68-82.

${ }^{9}$ Ibidem, s. 68.

${ }^{10}$ Ibidem, s. 78. 
komunikacji, w którym wykorzystywany jest Internet, postuluje się, ażeby mieć również na uwadze: zdolności organizacyjne instytucji publicznych oraz postawy i potrzeby społeczeństwa.

Kolejna praca autorstwa F. Wijnhovena, M. Ehrenharda i J. Kuhna dotyczy koncepcji otwartego rządzenia oraz partycypacji społecznej. Przeprowadzona przez badaczy ankieta na terenie Niemiec przyniosła ważne wnioski świadczące o tym, że informacja dystrybuowana poprzez Internet wpływa na kształtowanie się świadomości społecznej. Wykazano jednak, że na zaangażowanie obywateli $\mathrm{w}$ proces współdecydowania $\mathrm{w}$ wymiarze lokalnym nie mają wpływu uwarunkowania socjoekonomiczne, a właśnie dobra dystrybucja informacji ${ }^{11}$. Kluczowym jednak elementem zaangażowania społeczeństwa jest poczucie relewantności działania. Mówiąc inaczej, gdy lokalna wspólnota będzie miała poczucie, że dany projekt jest ważny dla nich, a nie jest jedynie wizerunkowym zabiegiem władz, wtedy poziom partycypacji wzrośnie. Kolejną istotną sprawą jest tradycja oraz kultura, tworząca się wiele lat, które wpływają na typy partycypacji w procesie politycznym ${ }^{12}$. W wymiarze funkcjonowania społeczeństwa informacyjnego warto zwrócić uwagę, że projekty administracji publicznej, których celem jest zwiększenie inkluzji społecznej w politykę lokalną, stają się również ważnym źródłem informacji dla mieszkańców. Można zatem sądzić, że jednym z podstawowych zadań, jakie stoją przed władzą, to nie tylko zachęcanie do partycypacji, a edukowanie na temat partycypacji, czyli wpływanie na kształt kulturowych typów aktywności społecznej, postaw obywatelskich i percepcji polityki ${ }^{13}$. Tylko takie działania władz będą prowadzić do zwiększenie efektywności partycypacji społecznej. Koresponduje to ze zdaniem D. Hilgersa, który uważa, że otwarta władza ma do spełnienia trzy cele: rozwój myśli i innowacyjności wśród obywateli, pozyskiwanie nowych przedstawicieli społeczeństwa do współpracy i stworzenie „demokracji współpracującej”"14. We wszystkich kluczową rolę odgrywa informacja oraz sposób jej dystrybucji i relewantności społecznego zaangażowania w cały proces.

Autorzy kolejnej pracy - hiszpańscy badacze E. Bonsón, S. Royo i M. Ratkai - stanowiącej ważny wkład w rozważania nad partycypacją społeczną z wykorzystaniem technologii informacyjnej - analizują zaangażowanie społeczeństwa w proces komunikacji w mediach społecznościowych na oficjalnych stronach samorządów lokalnych na portalu Facebook. Badania te zostały przeprowadzone w: Niemczech, Austrii, Belgii, Francji, Grecji, Włoszech, Luksemburgu, Portu-

${ }^{11}$ F. Wijnhoven, M. Ehrenhard, J. Kuhn, Open government objectives and participation motivations, „Government Information Quarterly” 2015, vol. 32, s. 38.

${ }_{12}$ Zob. R. Putnam, Demokracja $w$ działaniu. Tradycje obywatelskie we wspótczesnych Włoszech, Kraków 1995.

${ }^{13}$ F. Wijnhoven, M. Ehrenhard, J. Kuhn, Open government..., s. 39.

14 Ibidem, s. 31. 
gali, Hiszpanii, Danii, Finlandii, Holandii, Szwecji, Irlandii i Wielkiej Brytanii ${ }^{15}$. Powodem podjęcia się tego zadania było przeświadczenie, dominujące wśród naukowców, że media społecznościowe są współcześnie najbardziej bezpośrednim i szybkim kanałem komunikacji zbiorowej ${ }^{16}$. Ich wynik pokazuje, że budowanie strategii komunikacyjnej stanowi bardzo trudne wyzwanie dla samorządów lokalnych. Z uwagi na pełną swobodę, jaka panuje w przestrzeni wirtualnej, oraz fakt, że obiorcy sami decydują o tym, co chcą oglądać, stwierdzono, że obywatele częściej reagują na wpisy lub informacje dotyczące ich życia codziennego niż na komunikaty dotyczące bieżącego funkcjonowania administracji publicznej. Innym ważnym wnioskiem jest to, że tego rodzaju komunikacja dwukierunkowa władz z obywatelami (taka, w której inni użytkownicy mediów społecznościowych mogą również wpływać na treści zamieszczane na oficjalnych stronach internetowych władz miasta) pozytywnie wpływa na zaangażowanie społeczne oraz świadomość lokalnej społeczności o bieżących procesach politycznych w wymiarze samorządowym ${ }^{17}$. Tworzy się zatem swego rodzaju wirtualna wspólnota, składająca się ze wszystkich, którzy chcą być jej częścią, czyli np.: pasjonatów lokalnych zabytków, ekologów, społeczników oraz zwykłych mieszkańców zainteresowanych polityką lokalną.

Warto zwrócić również uwagę na artykuł B.J. Kima z Korei Południowej dotyczący efektywności: polityki, działania zbiorowego obywateli oraz dostępu do informacji i poziomu zaufania do władzy i współobywateli ${ }^{18}$. Definicja skuteczności, jaka została przyjęta przez badacza, brzmi: ,indywidualna aktywność polityczna, która ma albo może mieć wpływ na proces polityczny - na przykład, czy warto wykonywać swoje obowiązki obywatelskie"19. Została ona poddana analizie w dwóch wymiarach: wewnętrznym i zewnętrznym. Pierwszy z nich odnosi się do wiary człowieka w to, że ma prawo wypowiadania się i zawsze zostanie wysłuchany. Drugi wymiar odnosi się do wiary w odpowiedzialność i skuteczność rządzących ${ }^{20}$. B.J. Kim wykazał, że owa skuteczność aktywności politycznej obywateli w wymiarze wewnętrznym i zewnętrznym w dużej mierze zależy od osobistych doświadczeń każdej jednostki. $Z$ tego względu doszedł on do wniosku, że aktywność w mediach społecznościowych nie wpływa na aktywność w realnym świecie tak bardzo jak kompetencje wypracowane w rzeczywistej działalności

${ }^{15}$ E. Bonsón, S. Royo, M. Ratkai, Citizens' engagement on local governments ' Facebook sites. An empirical analysis: The impact of different media and content types in Western Europe, Analyse of social media, „Government Information Quarterly” 2015, vol. 32, s. 55.

${ }^{16}$ Ibidem, s. 54.

17 Ibidem, s. 60.

18 B.J. Kim, Political efficacy, community collective efficacy, trust and extroversion in the information society: Differences between online and offline civic/political activities, „Government Information Quarterly" 2015, vol. 32, s. 43-51.

19 Ibidem, s. 44.

${ }^{20}$ Ibidem, s. 48. 
obywatelskiej ${ }^{21}$. Można zatem stwierdzić, że Internet stał się medium, umożliwiającym swobodne zabieranie głosu na różny temat, jednakże nie jest on prawdziwym źródłem aktywności obywatelskiej, a jedynie jej emanacją w wirtualnym świecie.

Przedstawione dokonania naukowców z różnych stron świata pokazują, że społeczeństwo informacyjne jest płaszczyzną wymagającą wnikliwych naukowych analiz, w szczególności w perspektywie rozwoju społeczeństwa obywatelskiego, którego wewnętrzny proces komunikacyjny coraz bardziej staje się zdominowany przez świat wirtualny.

\section{Aspekty normatywne}

Wyzwaniem, przed jakim współcześnie stoją badania nad społeczeństwem obywatelskim, jest wpływ nowoczesnych technologii na sferę aktywności obywatelskich oraz relacji międzyludzkich. Powszechny dostęp do Internetu oraz panujący w nim chaos informacyjny powoduje, że procesy zachodzące w społeczeństwie oraz polityce odbywają się znaczniej szybciej, niż miało to miejsce jeszcze kilkadziesiąt lat temu. W wymiarze partycypacji społecznej również widać ten niepokojący trend. Nie należy jednak bagatelizować wpływu Internetu na sferę aktywności obywatelskich. Zmiany zachodzące w niej należy rozpatrywać w wymiarze ilościowym i jakościowym. Pierwszy z nich dostarcza nam informacji o tym, czy wykorzystanie technologii informacyjnych wpływa na zwiększenie zainteresowania aktywnościami obywatelskimi wśród mieszkańców. Drugi z nich pozwala uzyskać informacje dotyczącej tego, czy wykorzystanie technologii informacyjnych wpływa na podniesienie jakości partycypacji społecznej, a zatem czy wypracowane przez wspólnotę rozwiązania lub podjęte przez nią decyzje są lepsze oraz bardziej aprobowane przez lokalną społeczność. Na koniec warto podpowiedzieć sobie na pytanie, czy fakt istnienia technologicznych udogodnień w partycypacji społecznej wpływa na sposób podejmowania aktywności obywatelskiej. Niniejsze pytania badawcze pozwolą jednocześnie na zweryfikowanie następujących hipotez:

H1: Technologia informacyjna wypełnia ważną rolę w procesie wdrażania instrumentów partycypacji społecznej.

H2: Wykorzystanie technologii informacyjnych nie wpływa na jakość społeczeństwa obywatelskiego.

Niniejsza praca ma charakter deskryptywno-eksplanacyjny i opiera się na własnych obserwacjach w wymiarze funkcjonowania budżetu obywatelskiego w Łodzi oraz Poznaniu, a jej celem jest ukazanie wpływu technologii informacyjnej na proces partycypacji społecznej.

${ }^{21}$ Ibidem, s. 49. 
W pierwszej kolejności wymaga analizy sam proces, w którym tworzy się społeczeństwo obywatelskie. W tym celu należy posłużyć się koncepcją kapitału społecznego stworzoną przez R. Putnama, jak również modelem analizy systemowej autorstwa D. Eastona, w którym kluczowym aspektem jest sprzężenie zwrotne, czyli oddziaływanie reakcji społeczeństwa na sygnał wejściowy do systemu politycznego, którym są podjęte działania ze strony rządzących ${ }^{22}$. Również ważnym w przypadku analizy społeczeństwa obywatelskiego jest kapitał społeczny. Zdaniem R. Putnama, stanowi on sieć relacji między ludźmi podejmującymi działania zbiorowe. Mogą to być: członkowie rodziny, sąsiedzi lub mieszkańcy miasta. Powstałe w wyniku tych stosunków więzi wpływają pozytywnie na poziom zaufana do pozostałych członków wspólnoty oraz na chęć współpracy między nimi w przyszłości ${ }^{23}$. Według R. Putnama istnieją dwa rodzaje kapitału społecznego. Pierwszym z nich jest łączący - wpływający na rozrost grupy osób wchodzących w relacje wzajemności. Drugi nosi nazwę spajający - konsolidujący grupę, wpływający na lojalność społeczną (wewnętrzną) $)^{24}$. Jak stwierdził Coleman, kapitał społeczny to fenomen, który istnieje tylko w relacjach między aktorami społecznymi ${ }^{25}$, relacjach, które same w sobie stanowią proces komunikacji.

Komunikacja polityczna pomiędzy władzami a społeczeństwem to w państwie demokratycznych sedno polityki. Probierzem stabilności takich systemów politycznych jest odbiór społeczny działań podejmowanych przez rządzących, czyli sprzężenie zwrotne, które dostarcza informacji na temat tego, czy decyzje władz są społecznie akceptowalne, czy mieszczą się w ramach powszechnie przyjętych prawideł polityki, jak również, czy nie sprzeniewierzają się wyznawanym przez społeczeństwo wartościom, takim jak np. demokracja, wolności i samorządność.

Wymienione koncepcje orbitują wokół relacji międzyludzkich w wymiarze politycznym, co przybliża je do pojęcia aktywności obywatelskiej, dlatego też stanowią doskonałe podstawy metodologiczne, które umożliwiają analizę funkcjonowania społeczeństwa obywatelskiego. Do osiągnięcia celu niniejszej pracy posłużą również wyniki ankiet ewaluacyjnych, przeprowadzanych po kolejnych dwóch edycjach budżetu obywatelskiego w 2014 i 2015 r. w Łodzi i Poznaniu, zawierające dane jakościowe prezentujące ocenę samego projektu, procesu jego wdrażania oraz efektów, w opinii lokalnej społeczności.

${ }^{22}$ D. Easton, A Systems Analysis of Political Life, New York 1965, s. 31.

${ }^{23} \mathrm{~W}$ ramach tej aktywności członkowie wspólnot wypracowują w swoim postępowaniu tzw. cnoty obywatelskie, o których więcej: R. Putnam, Demokracja w działaniu..., s. 33.

${ }^{24}$ Ibidem, s. 40.

${ }^{25}$ E.J. Sommerfeldt, The civility of social capital: Public relations in the public sphere, civil society and democracy, „Public Relations Review” 2013, vol. 39, s. 284. 


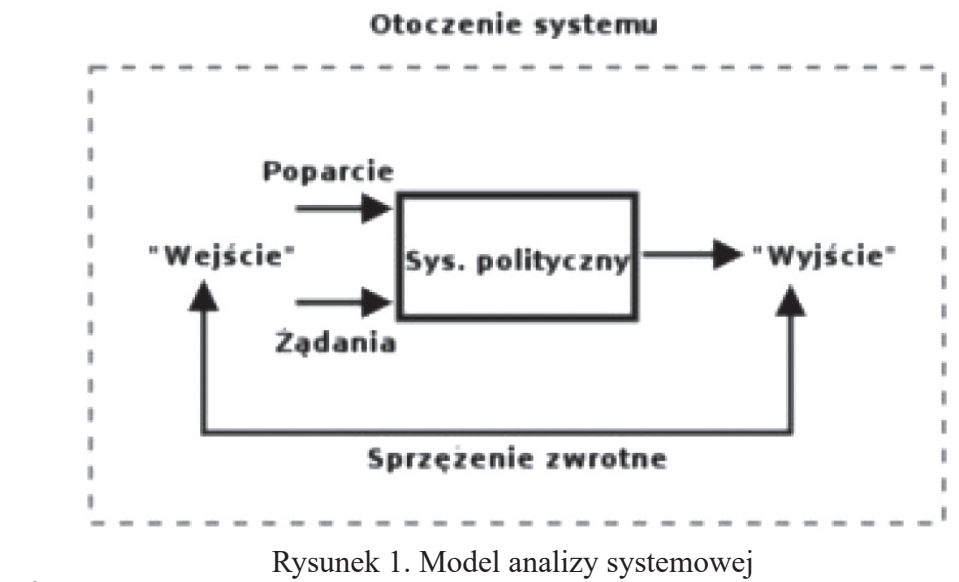

Źródło: D. Easton, A Systems Analysis of Political Life, New York 1965, s. 32.

\section{Aktywność obywatelska w wymiarze ilościowym}

Niezwykle istotną kwestią z punktu widzenia aktywnego obywatela jest dostęp do informacji na temat możliwości podejmowania działań wspólnotowych. $\mathrm{Z}$ tego względu warto przyjrzeć się ankietom ewaluacyjnym kolejnych edycji budżetu obywatelskiego w Łodzi i Poznaniu ${ }^{26}$. Wynika z nich, że w Łodzi podstawowym źródłem wiedzy na temat partycypacji jest Internet ${ }^{27}$. W 2014 r. ponad 59\% ankietowanych stwierdziło, że ich źródłem informacji na temat odbywającej się kolejnej edycji budżetu obywatelskiego były portale społecznościowe. W dalszej kolejności odpowiadali, że była to strona internetowa budzet.dlalodzi.info (47\%) oraz strona internetowa Urzędu Miasta Łodzi (32,2\%). Na dalszych miejscach znaleźli się: znajomi $(31,3 \%)$ i rodzina $(7,8 \%)$. W przypadku działań toczonych w ramach spotkań lokalnej wspólnoty ankietowani dali jasną odpowiedź, że tylko dla niewielu z nich tego rodzaju wydarzenia stanowiły źródło informacji. Wyniki te prezentują się następująco: spotkania informacyjne z mieszkańcami - 13,9\%, impreza „Sobota z budżetem obywatelskim” na ul. Piotrkowskiej - 10,4\%. W kolejnym roku tendencja ta nie uległa zmianie ${ }^{28}$. Zdaniem $70 \%$ ankietowanych, źródłem informacji o budżecie obywatelskim była strona internetowa Urzędu Miasta Łodzi, a w dalszej kolejności portale społecznościowe - 33\%, znajomi - 31\%,

${ }^{26}$ Dla Łodzi liczebność próby wyniosła w roku $2014 \mathrm{~N}=115$, a w $2015 \mathrm{r} . \mathrm{N}=138$. W Poznaniu liczebność próby wyniosła $\mathrm{N}=209 \mathrm{w} 2014 \mathrm{r}$. i N = 262 w $2015 \mathrm{r}$.

27 Wyniki ankiety ewaluacyjnej II edycji Budżetu Obywatelskiego dla Eodzi, http://uml.lodz.pl/ budzet_obywatelski/budzet_obywatelski_na_2015/ewaluacja/(dostęp 28.04.2016).

${ }^{28}$ Ankieta ewaluacyjna III edycji Budżetu Obywatelskiego dla Łodzi, http://uml.lodz.pl/get. php?id=15091 (dostęp 28.04.2016). 
strona internetowa budzet.dlalodzi.info $-24 \%$ oraz rodzina $-19 \%$. Spotkania informacyjne z mieszkańcami oraz cykliczna impreza „Sobota z budżetem obywatelskim" na ul. Piotrkowskiej osiągnęły wyniki poniżej $10 \%$.

Kolejnym przykładem jest Poznań, z którego ankiet ewaluacyjnych wynika, że podstawowym źródłem informacji dla poznaniaków o budżecie obywatelskim jest również Internet ${ }^{29}$. W 2014 r. aż 43\% ankietowanych stwierdziło, że są to portale społecznościowe, $31 \%$ znajomi, $24 \%$ strona internetowa www. poznan.pl/budzetobywatelski, 22\% strona internetowa www.poznan.pl. Rodzina w tym zestawieniu osiągnęła wynik $9 \%$, natomiast debaty z mieszkańcami na etapie składania wniosków zaledwie 5\%. W kolejnym roku rozkład ten stał się jeszcze bardziej jednolity, gdyż 39\% odpowiedziało, że źródłem był ogólnie rozumiany Internet, 10\% wyszczególniło portale społecznościowe, a pozostałe wyniki, czyli rodzina, sąsiedzi, szkoła, spotkania z mieszkańcami i kościół, zdobyły poniżej $10 \%{ }^{30}$.

Zaprezentowane dane pozwalają sądzić, że Internet stał się podstawowym źródłem komunikacji w przypadku budżetu obywatelskiego. Jedyną mogącą mu się równać instancją są znajomi, do których opinii niekiedy się odwołujemy. Należy jednak pamiętać, że w dzisiejszych czasach duża część interakcji międzyludzkich również zeszła do poziomu wirtualnego, dlatego nie sposób całościowo zbadać stopnia zaangażowania w proces partycypacji społecznej. Kolejną interesującą kwestią jest znaczący przyrost zainteresowania stronami internetowymi samorządu terytorialnego, który z pewnością ma walor nie tylko informacyjny, ale i edukacyjny, pozytywnie wpływając na świadomość społeczną na temat realiów bieżącej polityki lokalnej.

Kolejną niezwykle ważną informacją dotyczącą ilościowej analizy partycypacji społecznej jest wykorzystanie Internetu w procesie głosowania we wszystkich badanych edycjach budżetu obywatelskiego. Jak można zauważyć, jedynie w Poznaniu w 2015 r. liczba głosów oddanych w formie tradycyjnej, papierowej była większa niż tych wysłanych przez Internet. Łódź jest natomiast przykładem miasta zdominowanego przez Internet ${ }^{31}$.

${ }^{29}$ Ewaluacja Poznańskiego Budżetu Obywatelskiego 2015, http://www.poznan.pl/mim/main/ewaluacjapoznanskiego-budzetu-obywatelskiego-2015,p,15574,27284,28881.html (dostęp 28.04.2016).

${ }_{30}$ Wyniki Ewaluacji Poznańskiego Budżetu Obywatelskiego 2016, http://www.poznan.pl/ mim/main/poznanskibudzet-obywatelski-2016,p,15574,29813.html (dostęp 28.04.2016).

${ }^{31}$ Przedstawione dane nie odzwierciedlają prawdziwej liczby osób biorących udział w głosowaniu, gdyż każdy głosujący mógł wypełnić więcej niż jedną kartę, np. na zadania dzielnicowe i ogólnomiejskie w Łodzi lub na zadania droższe i tańsze w Poznaniu. 
Tabela 1. Oddane głosy

\begin{tabular}{|l|c|c|c|}
\hline \multicolumn{1}{|c|}{ Miasto } & Poprzez Internet & W formie papierowej & Łączna liczba głosów \\
\hline Łódź BO 2015 & 191000 & 76000 & 267475 \\
\hline Łódź BO 2016 & 108000 & 70000 & 178000 \\
\hline Poznań BO 2015 & 20908 & 33369 & 54277 \\
\hline Poznań BO 2016 & 52997 & 20139 & 73136 \\
\hline
\end{tabular}

Źródło: opracowanie własne.

Internet odgrywa również bardzo ważną rolę w procesie podejmowania decyzji, na który z projektów warto zagłosować. Na pytania dotyczące czynników wpływających na wybór zadania w Łodzi w 2014 r. ankietowani odpowiedzieli, że były to: informacje rozpowszechniane przez wnioskodawców - ok. 36,3\%, skrócone opisy zadań zamieszczone na stronie internetowej Urzędu Miasta Łodzi - 33,6\%, informacje zawarte w skanach wniosków do budżetu obywatelskiego zamieszczone na stronie internetowej Urzędu Miasta Łodzi - 30\%, a w dalszej kolejności informacje dostępne na stronie internetowej budzet.dlalodzi.info $-23 \%$, opinie znajomych $-12,4 \%$ i rodziny $-9,73 \%$. W roku 2015 wyniki te ksztaltowały się następująco: opinie członków rodziny, znajomych $-26,8 \%$, informacje dostępne na stronie internetowej uml.lodz.pl/budzet_obywatelski - 26,1\%, informacje rozpowszechniane przez wnioskodawców $-24,64 \%$, informacje dostępne na stronie internetowej budzet.dlalodzi.info - 12,3\%.

W Poznaniu dominującym miejscem kształtującym opinie mieszkańców w 2014 r. była strona internetowa www.poznan.pl/budzetobywatelski (42\%). W drugiej kolejności poznaniacy biorący udział w ankiecie uznali, że były to skrócone opisy zadań zamieszczone na stronie internetowej www.poznan.pl (36\%). Na dalszych miejscach znalazły się: informacje rozpowszechniane przez wnioskodawców (35\%), informacje we wnioskach na stronie internetowej www.poznan.pl/budzetobywatelski $(24 \%)$ oraz opinie znajomych (16\%). W roku 2015 rozkład ten prezentował się następująco: $40 \%$ - informacje dostępne na www.poznan.pl/budzetobywatelski, $36 \%$ - skrócone opisy projektów zamieszone na stronie internetowej Urzędu Miasta, 34\% - informacja na karcie do głosowania, 31\% - informacje rozpowszechnione przez wnioskodawców, $23 \%$ - rekomendacje rodziny/znajomych.

Z powyższych danych wynika, że osoby decydujące się na partycypowanie w budżecie obywatelskim starają się sami znaleźć informacje na temat zgłaszanych projektów u źródła, czyli na oficjalnych stronach internetowych. Następnie posiłkują się opiniami osób bliżej im znanych, którym ufają lub też kształtują swoje zdanie w ramach pozyskiwania bezpośrednich informacji od samych wnioskodawców. Należy jednak przypuszczać, odwołując się do roli technolo- 
gii informacyjnej w procesie procedowania budżetu obywatelskiego, że kontakt ten między głosującymi a wnioskodawcami również odbywa się w dużej części w Internecie.

Zebrane dane pozwalają sądzić, że Internet stał się dominującym miejscem aktywności obywatelskich mieszkańców Łodzi i Poznania. Na poczet pozytywnych aspektów należy zaliczyć to, że partycypujący, dążąc do uzyskania informacji o budżecie obywatelskim, częściej zaglądają na strony internetowe administracji samorządowej, tym samym zwiększając swoją wiedzę na temat bieżącej polityki lokalnej oraz kształtując świadomość na temat potrzeb lokalnej społeczności. Bardzo ważny jest również kontakt głosujących z wnioskodawcami, jednakże zauważalnie istotnym problemem jest zmarginalizowanie spotkań lokalnej społeczności zarówno z wnioskodawcami, jak i urzędnikami. Brak tym samym okazji do konfrontacji swoich poglądów oraz wspólnej dyskusji nad potrzebami miasta w świecie rzeczywistym, gdyż, jak wiemy, dyskurs prowadzony w sieci wirtualnej nie posiada cech opiniodawczego i efektywnego środka komunikacji.

\section{Aktywność obywatelska w wymiarze jakościowym}

Kolejną kwestią wymagającą analizy jest jakościowy aspekt partycypacji społecznej. Odwołując się ponownie do ankiet ewaluacyjnych kolejnych dwóch edycji budżetu obywatelskiego w Łodzi i Poznaniu, możemy sprawdzić, co zdaniem mieszkańców było najsłabszym punktem partycypacji, a co najmocniejszym i jak generalnie oceniają ideę budżetu partycypacyjnego. $Z$ danych dotyczących jego II edycji w Łodzi wynika, że ocena samego projektu jako pobudzającego społeczeństwo obywatelskie do działania waha się pomiędzy: raczej pozytywna $(33,04 \%)$ a raczej negatywna $(24,35 \%)^{32}$. Zauważalna jest jednak tendencja wzrostowa w pozytywnym postrzeganiu budżetu obywatelskiego, gdyż w 2015 r. opinie oscylowały między: zdecydowanie pozytywnie $(29,71 \%)$ a raczej pozytywnie $(42,75 \%)^{33}$. W Poznaniu w 2014 r. ocena ta była raczej pozytywna (43\%), a rok później ogólnie pozytywna ${ }^{34}$. Najgorzej ocenianym aspektem całej procedury była w Łodzi w 2014 r. weryfikacja wniosków (42,20\%), a w 2015 r. niemal ex aequo: zaprezentowanie wyników (30\%), informowanie o budżecie obywatelskim (26\%)

32 Wyniki ankiety ewaluacyjnej II edycji Budżetu Obywatelskiego dla Lodzi, http://uml.lodz.pl/ budzet_obywatelski/budzet_obywatelski_na_2015/ewaluacja/ (dostęp 28.04.2016).

${ }^{33}$ Ankieta ewaluacyjna III edycji Budżetu Obywatelskiego dla Łodzi, http://uml.lodz.pl/get. php?id=15091 (dostęp 28.04.2016).

${ }^{34}$ Ewaluacja Poznańskiego Budżetu Obywatelskiego 2015, http://www.poznan.pl/mim/main/ewaluacjapoznanskiego-budzetu-obywatelskiego-2015,p,15574,27284,28881.html (dostęp 28.04.2016). Wyniki Ewaluacji Poznańskiego Budżetu Obywatelskiego 2016, http://www.poznan.pl/mim/main/poznanski -budzet-obywatelski2016,p,15574,29813.html (dostęp 28.04.2016). 
oraz weryfikacja wniosków (25\%). W Poznaniu natomiast najgorszą notę uzyskało w 2015 r. głosowanie, liczenie i ogłaszanie wyników (37\%) oraz ocena i weryfikacja projektów (22\%). Za najlepiej postrzegany element budżetu obywatelskiego uznano w Łodzi: informowanie o budżecie obywatelskim (68,70\%) w 2014 r. oraz również ex aequo: informowanie o budżecie obywatelskim (39,86\%), głosowanie $(36,96 \%)$ oraz zaprezentowanie wyników $(28,99 \%)$. Widać zatem, że zdania co do całej procedury są podzielone i ma ona wielu zwolenników i krytyków. Złe zdanie na temat budżetu obywatelskiego nie wynika z niezgody co do idei, ale samego jej wdrażania. Sposób przeprowadzania niektórych etapów budżetu pozostawia wiele do życzenia, o czym wiedzą mieszkańcy, urzędnicy i politycy.

Ocena dostępności informacji na temat kolejnych edycji budżetu obywatelskiego jest równie istotna w przypadku procesu komunikacyjnego mającego miejsce w sferze samorządowej między władzą a społeczeństwem obywatelskim. We wszystkich przypadkach jest ona uważana z pozytywną, jednakże, jak wcześniej zostało nadmienione, znakomita grupa osób, zarówno partycypujących, jak i urzędników przygotowujących całą procedurę, zdaje sobie sprawę z niedociągnięć tego instrumentu polityki. Dla przykładu, ocenę pozytywną wystawiło w Łodzi w 2014 r. 55,65\%, w 2015 48,56\%, a w analogicznym czasie w Poznaniu 43\%.

Ostatnią ważną kwestią wymagającą analizy w wymiarze jakościowym jest opinia mieszkańców o sposobach głosowania. Zdaniem ankietowanych biorących udział w głosowaniu w Łodzi w 2014 r., za zdecydowanie pozytywne uważa głosowanie przez Internet aż 49,11\%. W $2015 \mathrm{r}$. pogląd ten podzieliło 77,54\% ankietowanych. W analogicznych okresach w Poznaniu wynik ten wynosi: 69\% i 60\%. Jedynym miastem, w którym dokonano oceny głosowania $\mathrm{w}$ tradycyjnej formie papierowej, jest Poznań, gdzie w 2015 r. zapytano ankietowanych, co sądzą na temat tego sposobu głosowania: $20 \% \mathrm{z}$ nich dało ocenę pozytywną.

Tabela 2. Ocena kolejnych edycji budżetu obywatelskiego w Łodzi i Poznaniu (w \%)

\begin{tabular}{|c|c|c|c|}
\hline Miasto & $\begin{array}{c}\text { Ocena ogólna kolejnej } \\
\text { edycji BO }\end{array}$ & Najgorzej oceniane & Najlepiej oceniane \\
\hline 1 & 2 & 3 & 4 \\
\hline Łódź 2015 & $\begin{array}{l}\text { Raczej pozytywna } \\
(33,04) \\
\text { Raczej negatywna } \\
(24,35)\end{array}$ & $\begin{array}{l}\text { Weryfikacja wniosków } \\
(42,20)\end{array}$ & $\begin{array}{l}\text { Informowanie } \\
\text { o budżecie } \\
\text { obywatelskim }(68,70)\end{array}$ \\
\hline Łódź 2016 & $\begin{array}{l}\text { Zdecydowanie } \\
\text { pozytywnie }(29,71) \\
\text { Raczej pozytywnie } \\
(42,75)\end{array}$ & $\begin{array}{l}\text { Zaprezentowanie } \\
\text { wyników (30) } \\
\text { Informowanie o budżecie } \\
\text { obywatelskim (26) } \\
\text { Weryfikacja wniosków (25) }\end{array}$ & $\begin{array}{l}\text { Informowanie } \\
\text { o budżecie } \\
\text { obywatelskim }(39,86) \\
\text { Głosowanie }(36,96) \\
\text { Zaprezentowanie } \\
\text { wyników }(28,99)\end{array}$ \\
\hline
\end{tabular}


Rozwój technologii informacyjnych szansą czy zagrożeniem dla społeczeństwa...

\begin{tabular}{|c|l|l|l|}
\hline \multicolumn{1}{|c|}{1} & \multicolumn{1}{|c|}{2} & \multicolumn{1}{|c|}{3} & \multicolumn{1}{c|}{4} \\
\hline Poznań 2015 & Raczej pozytywna (43) & n/d & $\begin{array}{l}\text { Możliwości głosowania } \\
\text { przez Internet (69) }\end{array}$ \\
\hline Poznań 2016 & n/d & $\begin{array}{l}\text { Głosowanie, liczenie } \\
\text { i ogłaszanie wyników (37) } \\
\text { Ocena i weryfikacja } \\
\text { projektów (22) }\end{array}$ & $\begin{array}{l}\text { Zgłaszanie projektów (69) } \\
\text { Opracowywanie } \\
\text { projektów (53) }\end{array}$ \\
\hline
\end{tabular}

Źródło: opracowanie własne.

Z tabeli 2 wynika, że głosowanie papierowe przestaje być pożądanym sposobem partycypacji wśród osób zaangażowanych w budżet obywatelski. Należy pamiętać, że wirtualna wersja tej procedury z każdym rokiem staje się coraz bardziej bezpieczna i uczciwa, czego dowodem jest wprowadzenie weryfikacji kodem SMS od 2015 r. w budżecie obywatelskim dla Łodzi. Niestety, osobiste doświadczenia pokazują, że głosowanie za pomocą kart papierowych zazwyczaj nie jest równie uczciwe. Zdarzały się w historii budżetu obywatelskiego w Łodzi przypadki, kiedy były one wypełniane przez pracowników służby zdrowia lub placówek oświatowych i dystrybuowane wśród pacjentów lub uczniów w celu zebrania jak największej liczby głosów pod określonymi projektami. Znane są również przypadki, że uczniowie dostawali gratyfikację w postaci dobrych ocen, gdy sami należycie zaangażowali się w proces „zbierania” głosów poparcia. Dlatego należy sądzić, że głosowanie przez Internet, w opinii publicznej, coraz bardziej jawi się jako bezpieczna i uczciwa forma głosowania. Wniosek ten poparty jest wynikami ewaluacji, które jasno pokazują, że preferowanym sposobem głosowania jest Internet lub Internet i za pomocą karty papierowej. Nie wystąpił żaden przypadek, w którym większa grupa osób podejmowałaby próby jednoznacznego wzmocnienia pozycji głosowania tradycyjnego.

Podsumowując opinie i oczekiwania mieszkańców Łodzi i Poznania w stosunku do budżetu obywatelskiego, należy zauważyć, że wszystkie one skłaniają się ku postulatowi profesjonalizacji budżetu partycypacyjnego i stałego podnoszeniu jakości wszelkich jego aspektów. Widać zatem potrzebę dbania o szczegóły oraz wyeliminowania aspołecznych i niezgodnych z prawem zachowań niektórych partycypujących w budżecie. Wyraźna jest potrzeba zbudowania więzi wspólnotowych opartych na współpracy i zaufaniu, a w sferze komunikacji społecznej - czystości i jasności oraz uczciwości w dystrybucji informacji. 


\section{Partycypacja społeczna przez Internet - podsumowanie}

Aktywność obywatelska coraz częściej przenosi się z ulic miast do sieci wirtualnej. Media społecznościowe oraz dedykowane partycypacji społecznej portale informacyjne stają się przestrzenią, w której współczesny człowiek żyje, z której czerpie informacje i na podstawie której wyrabia własny pogląd na świat. Powszechny dostęp do Internetu otworzył nowy etap w relacjach administracji publicznej (władzy) z obywatelami. Ta pierwsza stara się projektować strategie komunikacyjne w takich sposób, aby „przypodobać się” lokalnym społecznościom. Mieszkańcy natomiast starają się odsiać z szerokiego strumienia te informacje, które są dla nich najważniejsze, odnoszące się bezpośrednio do codziennego życia. Pogodzić interesy obu stron mogą portale społecznościowe, które umożliwiają komunikację dwukierunkową. Należy więc stwierdzić, że Internet, a dokładniej media społecznościowe i dedykowane portale, jako element rozwoju technologii informacyjnej mogą wpływać pozytywnie na rozwój kapitału społecznego. W szczególności zdają się być przydatne w procesie rozwoju kapitału spajającego, czyli wpływającego na lojalność społeczną lokalnych wspólnot lub pasjonatów w ramach określonych sfer polityki lokalnej. Nie należy jednak sądzić, że rozwiązania technologiczne będą $p a-$ naceum na wszelkie trudności partycypacji społecznej i staną się portalem do świata aktywnych obywateli. Internet nie ma takich możliwości, aby wpłynąć na świadomość mieszkańców tak bardzo, jak mogą to zrobić spotkania lokalnych społeczności. Wnioskiem płynącym z tych rozważań jest to, że kapitał społeczny łączący buduje się na ulicach, w ramach spotkań, debat, nawet kłótni, lecz nie w Internecie. Dlatego też bez rzeczywistej interakcji między ludźmi nie osiągniemy społeczeństwa obywatelskiego najwyższej jakości, a jedynie jego protezę, wirtualną emanację naszych wyobrażeń i życzeń o nim.

Ustanowienie nowych zasad relacji władzy z obywatelami dostarcza doświadczeń, które wpłyną na poziom partycypacji społecznej mieszkańców lokalnych wspólnot w przyszłości. Najważniejszym czynnikiem wpływającym na ten stan jest relewantność podejmowanych działań. Obywatele muszą wiedzieć, po co to robią i w niedalekiej przyszłości widzieć realny pożytek ich wysiłku. Dlatego też tak istotną rolę odgrywa dostęp do nieprzekłamanej, konkretnej i szybkiej informacji. Gdy ten stan zostanie osiągnięty, sprzężenie zwrotne docierające do osób sprawujących władze będzie motywowało do dalszych działań aktywizujących społeczeństwo, a co najważniejsze, potwierdzało, że zmiany idą w dobrym i akceptowalnych powszechnie kierunku.

Z powyższych rozważań płynie wniosek, że technologia informacyjna wpływa na zwiększenie zainteresowania aktywnościami obywatelskimi wśród mieszkańców, natomiast stan ten wymaga innego rodzaju stabilizatorów, które spowodują, że obywatele nie zniechęcą się do współpracy z poczuciem wykorzystania czy oszukania. Jednocześnie należy stwierdzić, że technologia informacyjna wpływa na 
podniesienie jakości partycypacji społecznej poprzez np. zapewnienie bezpiecznej i uczciwej procedury głosowania. Jednocześnie jednak nie pobudza mieszkańców do wzajemnych relacji, debat, tym samym stanowiąc nieadekwatny substytut dla tradycyjnych spotkań lokalnej społeczności. Należy również stwierdzić, że technologia informacyjna wpływa na sposób podejmowania aktywności obywatelskiej.

Zgodnie z powyższymi ustaleniami hipotezę pierwszą mówiącą o tym, że technologia informacyjna wypełnia ważną rolę w procesie wdrażania instrumentów partycypacji społecznej, należy uznać za prawdziwą, gdyż pozwala ona ludziom szybko i łatwo brać udział w podejmowaniu decyzji politycznych na szczeblu lokalnym, jednocześnie umożliwiając im zwiększenie ich świadomości i wiedzy politycznej. Kolejną hipotezę odnoszącą się do wpływu technologii informacyjnej na jakość społeczeństwa obywatelskiego należy uznać za błędną, ponieważ nie istnieją wystarczające przesłanki, by uznać, że Internet i różnego rodzaju portale informacyjne, media społecznościowe wpływają na powstanie więzi społecznych, podniesienie poziomu zaufania i współpracy między obywatelami. Paradoksalnie, sieć wirtualna stała się instrumentem w celu stworzenia bezpiecznej płaszczyzny do partycypacji społecznej niejako w oderwaniu od realiów społecznych. Trudno uznać ten fakt za wpływający pozytywnie na rozwój społeczeństwa obywatelskiego. Można jedynie mieć nadzieję, że powstałe relacje i więzi między użytkownikami sieci staną się na tyle silne, aby mogły interferować na stosunki społeczne w rzeczywistym świecie. $\mathrm{Z}$ tego względu należy stwierdzić, że rozwój technologii informacyjnej jest niewątpliwie szansą dla rozwoju społeczeństwa obywatelskiego. Jest on jednak pełen pułapek, których należy unikać oraz dalej rozwijać i umacniać poczucie obywatelskości, tworząc tym samym społeczeństwo obywatelskie najwyższej próby.

\section{Bibliografia}

Ankieta ewaluacyjna III edycji Budżetu Obywatelskiego dla Lodzi, http://uml.lodz.pl/get. php?id=15091 (dostęp 28.04.2016).

Bonsón E., Royo S., Ratkai M., Citizens ' engagement on local governments ' Facebook sites. An empirical analysis: The impact of different media and content types in Western Europe, Analyse of social media, „Government Information Quarterly” 2015, vol. 32.

Drucker P.F., The Knowledge Economy, Boston 1998.

Easton D., A Systems Analysis of Political Life, New York 1965.

Ewaluacja Poznańskiego Budżetu Obywatelskiego 2015, http://www.poznan.pl/mim/ main/ewaluacjapoznanskiego-budzetu-obywatelskiego-2015,p,15574,27284,28881. html (dostęp 28.04.2016).

Kim B.J., Political efficacy, community collective efficacy, trust and extroversion in the information society: Differences between online and offline civic/political activities, „Government Information Quarterly” 2015, vol. 32.

Kolczyński M., Strategie komunikowania politycznego, Katowice 2008. 
Krzysztofek K., Szczepański M.S., Zrozumieć rozwój-od społeczeństw tradycyjnych do informacyjnych, Katowice 2002.

Misuraca G., Codagnone C., Rossel P., From practice to theory and back to practice: Reflexivity in measurement and evaluation for evidence-based policy making in the information society, „Government Information Quarterly” 2013, vol. 30.

Pietrzyk-Reeves D., Idea społeczeństwa obywatelskiego, współczesna debata i jej źródła, Wrocław 2004.

Putnam R., Demokracja w działaniu. Tradycje obywatelskie we współczesnych Włoszech, Warszawa 1993.

Putnam R., Demokracja w działaniu. Tradycje obywatelskie we współczesnych Włoszech, Kraków 1995.

Sommerfeldt E.J., The civility of social capital: Public relations in the public sphere, civil society and democracy, „Public Relations Review”2013, vol. 39.

Szewczyk A., Społeczeństwo informacyjne - problemy rozwoju, Warszawa 2007.

Wijnhoven F., Ehrenhard M., Kuhn J., Open government objectives and participation motivations, „Government Information Quarterly” 2015, vol. 32.

Wyniki ankiety ewaluacyjnej II edycji Budżetu Obywatelskiego dla Łodzi, http://uml.lodz. pl/budzet_obywatelski/budzet_obywatelski_na_2015/ewaluacja/ (dostęp 28.04.2016).

Wyniki Ewaluacji Poznańskiego Budżetu Obywatelskiego 2015, http://www.poznan.pl/mim/main/ poznanski-budzet-obywatelski-2015,p,15574,27284,28881.html (dostęp 28.04.2016).

Wyniki Ewaluacji Poznańskiego Budżetu Obywatelskiego 2016, http://www.poznan.pl/mim/ main/poznanskibudzet-obywatelski-2016,p,15574,29813.html (dostęp 28.04.2016).

\section{Mateusz Radziszewski}

\section{Развитие информационных технологий - шанс или угроза гражданскому обществу?}

В статье поднимается вопрос гражданского общества в контексте развития информационных технологий. В первой части статьи осуществлен анализ исследований использования информационных технологий в процессе общественной партиципации. В дальнейшем, анализу подвержено было использование информационных технологий в рамках функционирования партиципационного бюджета в Лодзи и Познани в 2014 и 2015 годах, а также его эффектов с точки зрения общественного участия, которое анализируется через призму концепции общественного капитала, созданной Р. Пэтнэмом, а также с точки зрения системного анализа Д. Истона.

Ключевые слова: информационные технологии, интернет, общественный капитал, гражданское общество, партиципационный бюджет. 


\section{Mateusz Radziszewski}

\section{Development of Information Technologies - opportunity or danger for Civil Society?}

The political participation of citizens is a fundamental element of a democratic system and guarantees the realization of democratic values. An important element of participation is the use of information technologies in this process. The first part of the article contains the worldwide research review of civil participation and the use of information technologies in the communication between the government and citizens. The next part is the analysis of the use of information technologies in a participatory budgeting in Lodz and Poznan in 2014 and 2015. The aim of this research is to find quantitative and qualitative dimension of civil participation in the virtual world. My research will use Robert Putnam's conception of social capital and D. Easton's „Systems Analysis of Politics”. The hypotheses are: H1: information technologies are an important part of civil participation process, H2: Use of information technologies has no influence on qualitative dimension of civil participation.

Keywords: information technologies, internet, social capital, civil society, participatory budgeting. 